\title{
Reforming Higher Education in Austria: Challenges and Problems
}

\section{Barbara Sporn}

Barbara Sporn is assistant professor in the Abteilung für Wirtschaftinformatik at the Wirtschaftuniversität Wein. Address: Wirtschaftsuniversität Wien, Augasse 2-6, A-1090 Wien, Austria. Email: <sporn@wu-wien.ac.at>.

A ustria has 12 federal universities, which vary in size and structure and fall into two broad categories: larger and more comprehensive institutions, consisting of a number of different faculties (e.g., the University of Vienna) and smaller "specialized" universities (e.g., Vienna University of Economics and Business Administration) that are more narrowly focused on the theoretical and applied disciplines. Additionally, a second institutional type (Fachbochschule), offering vocational training, was established in 1993 by federal legislation, with special regulations governing the access and fees of new students.

Currently, Austria has no private higher education market. Access to public universities is open to all high school graduates with a diploma. There are no tuition costs or fees in Austrian higher education (except for a small fee for the Austrian Student Union). Austrian universities are financed almost exclusively by the federal budget. Only about 3 percent of total expenditures derive from private sources or research funds. In 1997, the university budget was ATS29.8 billion, an amount representing 4 percent of the total federal budget and 1.2 percent of the Austrian GDP. During the 1996-97 academic year, Austria had 213,500 students enrolled at public universities. Faculty in the same time period numbered 14,100 , of which only 1,650 were professorsthe rest were considered assistant-level academic personnel.

\section{Access to public universities is open to all high school graduates with a di- ploma. There are no tuition costs or fees in Austrian higher education.}

During the 1990s, expenditure per student has been decreasing dramatically. Some universities have a student/faculty ratio of close to 200:1. The results have been high dropout rates, a lengthier average time to degree, heavier teaching loads, and a decreasing commitment to research. In 1994 Austria joined the European
Union, thereby increasing international competition in the higher education area and pressing the state to reduce its budget. Additionally, a high degree of bureaucratic regulation and the centralization of decision making at the ministerial level have long impeded efforts to meet the needs of a rapidly changing environment.

\section{During the 1990s, expenditure per stu- dent has been decreasing dramatically.}

\section{Reform Proposals}

In 1993 the Ministry of Education mandated a reorganization for "its" universities. Accordingly, the University Organization Act of 1993 called for the reorganization of the internal governance structures of the university. The major goals of the 1993 reforms were to:

- increase institutional autonomy by deregulation and decentralization of responsibilities-especially in the area of budget, personnel, and organization at individual universities;

- increase management capacity of universities by strengthening the role of top management positions such as rectors, vice rectors, or deans;

- increase efficiency of governance structures by making decision-making bodies leaner and decentralizing decision-making power to an appropriate level;

- increase the external focus of universities by establishing a board of trustees for each university consisting of alumni, business managers, and members of institutions of public interest; and

- increase involvement of nonuniversity constituencies by establishing a National University Board, consisting of experts from inside and outside universities to advise the ministry on new program development, and planning, resource allocation, and evaluation procedures for the university sector at large.

The 1993 reforms aimed at increased managerialism of universities through decentralization and deregulation of responsibilities, better division of labor between operative and strategic units inside universities, and evaluation of programs, processes, boards, and buffer organizations. In effect, the state has been moving from tight control to a supervisory function. A number of problems concerning their implementation have arisen in Austria today. 


\section{The Ministry and National University Board}

It is not clear what the new function of the ministry will be. Although delegation and decentralization are part of the reform, the ministry still claims the power to evaluate university processes and functions. Trust and support, together with open channels of information, are still not in place. Additionally, the National University Board has yet to build up expertise in fulfilling its critical function. Although responsible for strategic planning and evaluation for the higher education sector, university representatives and members of the board engage in little communication and exchange.

\section{Lay Administration}

Austrian universities are characterized by an administration consisting of either civil servants trained in the execution of orders or lay administrators recruited from the faculty to serve in top positions. With the new job description for rectors or deans, these professors will need different tools and skills to fulfill their tasks. But no support is forthcoming at this point from the ministry or the institution. Financial incentives for professors to get involved in administration are completely missing. Hence, the selection process becomes arbitrary and the implementation of the 1993 reforms is dependent on the commitment or motivation of individuals.

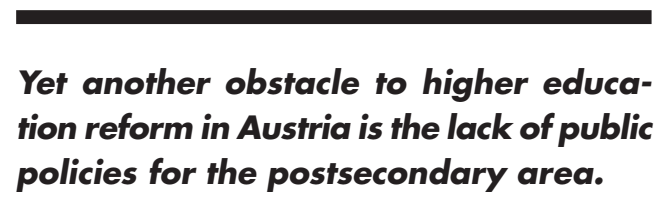

\section{Relationship between Universities and the State}

Traditionally, the Austrian higher education system has been characterized by a strained relationship between the universities and the state. The reforms require greater communication and collaboration and rational dialog and decision making. Schooled in the old system, however, both parties stick to their positions, and constructive discussion becomes impossible.

\section{The Absence of Public Policy}

Yet another obstacle to higher education reform in Austria is the lack of public policies for the postsecondary area. By creating vocational institutions and increasing the autonomy of universities, it seems that a diversification of products and services and the development of management capacity are intended. But long-term public strategies and goals regarding teaching and research at Austrian universities are missing. As a consequence, the motivation to reform institutions from within is lacking.

\section{Institutional Research and Goals}

Looking at the internal prerequisites of implementing the mandated reform, two problems become apparent. First, most Austrian universities do not have the strategies, goals, or mission statements that would inform their decision making. For example, with the new budgeting procedure, projects have to be prioritized. Of course, a concise strategy for the institution would help to set standards for ranking projects. Currently, most Austrian universities do not have a strategic plan.

\section{These changes imply a dramatic shift in the culture and conception of the higher education system in Austria.}

A second problem is the need for data about internal and external conditions. In the United States, institutional research offices provide data about students, graduates, stakeholders, profits, costs, and the like for decision making. In Austria the idea of institutional research does not even exist. All data are still collected at the ministerial level and distributed to the universities. More detailed information about students, faculty, administration, and the environment, as well as educational processes and the costs, is needed at each university to support managerial decision making.

Despite these problems, the reform of Austrian higher education is moving in the right direction. Institutions are now able to determine their own fates and develop programs accordingly. New forms of cooperation between the state, the National University Board, and all higher education institutions need to be developed. Professional university management is necessary to meet the claims and challenges of the new information society. An open discussion between all representatives would help to rethink long traditions.

These changes imply a dramatic shift in the culture and conception of the higher education system in Austria, and cannot, therefore, be achieved overnight. Only time will tell if the 1993 reforms will initiate a lasting process of change.

Internet Resource

For more information on international issues in higher education, visit the Center's website, located at:

$$
\text { http://www.bc.edu/bc_org/avp/soe/cihe/ }
$$

